\title{
THE EFFECTS OF INFLATION, RISK, AND MONEY SUPPLY ON MUTUAL FUNDS PERFORMANCE
}

\author{
Leonardo Cheng ${ }^{1}$; Kartika Dewi ${ }^{2}$ \\ ${ }^{1,2}$ Bina Nusantara University, \\ J1. Jalur Sutera Barat Kav.21, Alam Sutera, Tangerang, 021-2977 9100, \\ ${ }^{1}$ leonardocheng1997@gmail.com; ${ }^{2}$ kdewi@binus.edu
}

Received: $10^{\text {th }}$ October 2019 / Revised: $9^{\text {th }}$ December $2019 /$ Accepted: $7^{\text {th }}$ March 2020

\begin{abstract}
This research aims to examine the effect of inflation, risk rate and money supply on the performance of stock mutual funds in the 2015-2017 period. This research uses purposive sampling and obtained 25 mutual funds stocks per year with a total sample of 75 samples. The analysis uses panel data regression with e-views version 9. The results show that inflation and money supply variable have a significant negative influence, while the risk rate variable has a significant positive influence. This shows that the performance of the stock mutual funds is influenced by macroeconomic factors such as inflation, the level of risk of each mutual fund product and the amount of money circulating in the community.
\end{abstract}

Keywords: Stock mutual funds performance, Inflation, Risk rate, Money supply.

\section{INTRODUCTION}

Indonesia is very rich in natural resources and population. Based on the report from Badan Pusat Statistik, population Indonesia reach 261.89 million people in 2017, which is ranked no 5 in the world 2017. Otoritas Jasa Keuangan (OJK) claimed only $29.9 \%$ of 261.89 recognized finance facility such as having an account in the bank. According to Chief Otoritas Jasa Keuangan, Mr. Sujanto, only a small percentage of people know about the capital market. From those population number, $29.9 \%$, only $4.4 \%$ knows the capital market in Indonesia. The knowledge of the capital market means the knowledge about investing in shares, obligation or mutual funds. There are many factors that contributed to this finance illiteracy, among them are inequality of internet access and inability or unwillingness to have the bank account. These basic two factors inhibit people to gain knowledge on how to invest in a more sophisticated capital market. Only $0.4 \%$ of 261.89 million people invested in the capital market with various stocks, bonds, marketable securities, mutual funds, derivatives and other financial instruments.

Mutual funds are growing these days, there are many opportunities and market-share that are open for people to invest money in mutual funds. According to Kustodian Sentral Efek Indonesia as of June 7, 2017, only 523.000 people invest in mutual funds. This number is representing only $0.2 \%$ of the Indonesian population. A survey conducted by Manulife Asset Management Indonesia (MAMI) found that low interest in investing in mutual funds is due to lack of knowledge and information regarding mutual fund performance, the advantages of saving money in mutual funds, the difference between saving and investment, and not knowing which one the best mutual fund to invest in. Based on these conditions, it is interesting to investigate the performance of mutual funds using macroeconomics variable namely inflation, risk, and money supply. This study is expected to help investors determine 
better financing decisions in choosing the best mutual funds.

This study is supported by the signalling theory. According to Brigham dan Houston (2010), "signal sent to investors by the company to give information to investors, help investors to take an economic decision, this information usually about company future performance". The purpose of sending signals to investors is to reduce asymmetry information. Better information can be taken when investors have information about the company and eventually the firm value also increases. Those signals can be good news or bad news, investors can interpret, digest and make decisions based on their interpretation.

A similar study was conducted by Nurcahya (2010) with the title "Reksa Dana di Indonesia: Analisis Kebijakan Alokasi Aset, Pemilihan Saham, dan Tingkat Risiko". The result indicated that risk has a significantly positive effect on mutual fund performance. The higher the risk the higher the mutual performance. This result is consistent with risk theory suggests that the bigger the risk the bigger the return. Another study that was done by Maulana (2013) titled "Pengaruh SBI, Jumlah uang beredar, Inflasi terhadap kinerja reksadana saham di Indonesia 2004-2012" shows that money supply has a positive significant effect on mutual fund performance. The increased money supply available in society increases makes the company has enough cash to invest in different forms of business and eventually it will increase firm value.

Using explanation condition and other previous studies, we proposed three hypotheses as follow:

1. Ha1: Inflation has an effect on mutual funds' performance

2. Ha2: Risk has an effect on mutual funds' performance

3. Ha3: Money supply has an effect on mutual funds' performance

\section{METHODS}

The data used in this study is secondary panel data which combines time-series and cross-section financial data. The population in this study is all mutual funds listed in Bursa Efek Indonesia over the period of 2015 to 2017.
A purposive sampling method is used in this study.

Criteria for the purposive sampling are:

1. The sample is mutual funds that have an effective date before January 2015.

2. The sample is active trading mutual funds for over the period 2015 to 2017.

3. The mutual funds issued daily Net Asset Value (NAV) per unit.

4. Data and information from the selected sample are publicly available

Based on sample criteria we collect 25 mutual funds for 3 years period so total sample data will be 75 mutual funds for the year 20152017 with helping from E-views 9. Table 1 is showing all the independent and dependent variables used in this study.

\section{RESULT AND DISCUSSIONS}

Table 2 shows the descriptive statistic for the sample. Based on table 2 we can conclude:

1. Inflation has value for mean 4.5742 with a median of 3.8092 . The maximum and minimum values of inflation are 6.3825 , and 3.5308. The value for the standard deviation is 1.2924 .

2. Risk has a mean value of 1.8617 with a median of 0.8422 . The maximum and minimum values of risk are 11.4161 and -2.3757 . The value of the standard deviation is 3.3106 .

3. Money supply has a mean value for mean 4.7398 with a median of 4.6985 . The maximum and the minimum value of inflation are 5.1632 and 4.3577. The value of the standard deviation is 0.3324 .

4. The performance of mutual funds has a mean value of 0.8780 and a median of 0.3148 . The maximum and minimum value of performance mutual funds are 9.3479 and -3.9522 . The value of the standard deviation is 2.7413 .

Chow test was done to choose the correct model whether using Common Effect or Fixed Effect. Based on Chow test, value for crosssection chi-square is 36.870165 with p-value is 0,0451 . Because p-value $<0,05$ then $\mathrm{H} 1$ accepted and model will be used is Fixed effect. Hausman test was done to confirm the correct model whether it will be used Fixed Effect or 
Random Effect. Based on the Hausman Test, value for chi-square cross-section random is 0,000 with $\mathrm{p}$-value 1.000 . Because $\mathrm{p}$-value > 0,05 then $\mathrm{H} 0$ accepted or model will be used is Random effect.

Lagrange was done to test whether the model will be Common Effect or Random Effect. Lagrange test was doing because there is inconsistency result in Chow and Hausman. Based on Lagrange-test, the value for crosssection Breusch-Pagan is 0.378924 with a pvalue of 0.5382 . Because p-value $>0,05$ then $\mathrm{H} 0$ accepted or appropriate model is Common Effect.

The regression equation form panel data test is follows:

$\mathrm{Y}=12.46075-0.300002$ INFLATION + 0.969256 TOTAL RISK - 2.534714 MONEY SUPPLY + e

Based on table 6 value for adjusted $R_{2}$ is 0.9998. Independent variables inflation, risk and money supply can explain mutual fund performance $98.98 \%$ and $0.02 \%$ will be explained by other variables outside independent variable have been chosen.

Based on F-test, value for F is 125913,7 with value prob F-statistic 0.000 which is less than required significant value 0.05 . It can be concluded that independent variables have effects on the dependent variable simultaneously.

Based on t-test, we can conclude for each independent variable as follow: Based on regression test, inflation has probability value 0 which is $<0,05$. We can conclude $\mathrm{H}_{0} 1$ rejected, and $\mathrm{H}_{\mathrm{a}} 1$ accepted. This means inflation influences the mutual fund's performance partially. With a negative coefficient value 0.300002 means inflation decrease and mutual fund's performance increase or inflation increase and mutual fund's performance decrease. This result agrees with Maulana (2013) and Sholihat (2015) which said inflation has negative coefficient with mutual fund's performance because prices will go up when inflation increase in which it will make all productions expense become expensive and selling expense will up and power of purchasing will decrease and it will effect on company profit and mutual fund itself because most people spent money on necessity first and the left income will be invested on mutual funds or other instruments

Based on regression test, risk has probability value 0.0000 which is $<0,05$. We can conclude $\mathrm{H}_{0} 2$ rejected, and $\mathrm{H}_{2} 2$ accepted. This means risk has an effect on mutual funds' performance partially. With a positive coefficient 0.969256 means total risk increase and mutual fund's performance increase. This result agreed with Nurcahya (2010) who said the more risks the more return on mutual fund's performance. This result is agreed with the economic theory on risk and return, the more expected return, the more risk must be bear. Risks can be managed to minimize the unexpected outcome with diversification on allocation. This result is not agreed with studied done by Sari (2012) who said risk has a negative correlation with the mutual fund's performance.

Based on the regression test, the total money supply has value 0.0000 which is $<0,05$. We can conclude $\mathrm{H}_{0} 3$ rejected, and HA3 accepted. This means risk has an effect on the mutual fund's performance partially. With a negative coefficient, -2.534714 means total money supply decrease and mutual fund's performance increase. This result agrees with Setiadi (2013) who said the more money supply in the society the less interest in investing mutual funds because people prefer to spend their money on consumer goods. This study does not consistent with Tandelilin (2001) who said increasing money supply will make the company has more money to expand its business and it will make more profit for the company and it will add more profit for the company and better mutual fund's performance. The more money supply will create higher purchasing power and the more profit on the company.

\section{CONCLUSION}

We examine the effect on inflation, risks and money supply toward mutual fund's performance over the period of 2015 to 2017. The results are inflation, risk, money supply influence the mutual fund's performance. Macroeconomic indicators can be used to predict the mutual fund's performance. For further study, interest rate from Bank Indonesia, exchange rate and mutual fund based on type can be used as independent variables 


\section{REFERENCES}

Badan Pusat Statistik. (2018), Jumlah Uang Beredar, diakses 20 Oktober 2018 dari www.bps.go.id

Bank Indonesia. (2018), Inflasi, diakses 20 Oktober 2018 dari www.bi.go.id

Bareksa. (2018), Return dan Tingkat Risiko Reksadana, diakses 20 Oktober 2018 dari www.bareksa.com

Brigham, H. (2010). Dasar-dasar Manajemen Keuangan Buku 1 (Edisi 11). Jakarta: Salemba Empat.

Indopremier. (2018), Cara Mengukur Risiko Reksadana, diakses 13 Oktober 2018 dari www.indopremier.com

Maulana, A. (2013). Pengaruh SBI, Jumlah Uang Beredar, Inflasi terhadap Kinerja. Jurnal Ilmu Manajemen Volume 1 No 3, 971-984.

Nurcahya, G. P., \& Bandi. (2010). Reksa Dana di Indonesia: Analisis Kebijakan Alokasi Aset, Pemilikan Saham, dan Tingkat Risiko. Simposium Nasional Akuntansi XIII Purwokerto 2010.

Otoritas Jasa Keuangan. (2018), Produk Reksadana, diakses 20 Oktober 2018 dari www.ojk.go.id
Portalreksadana. (2018), Nilai Aktiva Bersih, diakses 23 Oktober 2018 dari www.portalreksadana.com

Sari, A. P., \& Purwanto, A. (2012). Analisis Kebijakan Alokasi Aset, Kinerja Manajer Investasi dan Tingkat Risiko terhadap Kinerja Reksadana Saham di Indonesia. Diponegoro Journal of Accounting Volume 1, Nomor 1, Tahun 2012, 1-14.

Setiadi, S. P. (2013). Analisis Pengaruh Jumlah Uang yang Beredar Terhadap Kinerja Reksadana Saham di Indonesia Periode 2002-2012. 1-7.

Sholihat, F., AR, M. D., \& Topowijono. (2015). Pengaruh Inflasi, Tingkat Suku Bunga Sertifikat Bank Indonesia \& Indeks Harga Saham Gabungan terhadap Tingkat Pengembalian Reksadana Saham. Jurnal Administrasi Bisnis Vol. 21 No.1 April 2015, 1-7.

Sugiyono. (2015). Metode Penelitian Kuantitatif, Kualitatif, dan R\&D. Bandung: CV. Alfabeta.

Tandelilin, E. (2001). Analisis Investasi dan Manajemen Portofolio. Edisi Pertama. Yogyakarta: BPFE. 
Table 1 Operational Variable

\begin{tabular}{|c|c|c|c|c|c|}
\hline & Variable & Keterangan & Scale & Formula Variable & Proxy \\
\hline $\begin{array}{l}\text { Dependent } \\
\text { Xariabel (y) }\end{array}$ & $\begin{array}{l}\text { Performance } \\
\text { Mutual } \\
\text { Funds }\end{array}$ & $\begin{array}{l}\text { Measure } \\
\text { performance } \\
\text { portfolio in } \\
\text { mutual funds }\end{array}$ & Ratio & $\begin{array}{l}\text { Sharpe Model } \\
S p=\frac{(A R p-A R f)}{\sigma p}\end{array}$ & Sharpe \\
\hline $\begin{array}{l}\text { Independent } \\
\text { Zariabel (x) }\end{array}$ & Inflation & $\begin{array}{l}\text { Measure } \\
\text { increasing price } \\
\text { in general using } \\
\text { Indeks Harga } \\
\text { Konsumen }\end{array}$ & Ratio & $\begin{array}{l}\text { Inflation Rate } \\
\frac{I H K n-I H K o}{I H K o} \times 100 \%\end{array}$ & IHK \\
\hline & Risk & $\begin{array}{l}\text { Measure } \\
\text { deviation } \\
\text { between actual } \\
\text { return with } \\
\text { expected return }\end{array}$ & Ratio & $\begin{array}{l}\text { Standard Deviation } \\
\sigma i=\sqrt{\frac{\sum_{i=1}^{n}\{X i-E(X i)\}^{2}}{N}}\end{array}$ & Std Dev \\
\hline & $\begin{array}{l}\text { Money } \\
\text { supply }\end{array}$ & $\begin{array}{l}\text { Measure } \\
\text { outstanding } \\
\text { money (M2). }\end{array}$ & Ratio & $\begin{array}{l}\text { Total number of outstanding } \\
\text { monev } \\
M 2=M 1+T D+S D\end{array}$ & M2 \\
\hline
\end{tabular}

Table 2 Descriptive Statistic Mutual Funds 2015 - 2017

\begin{tabular}{lcccc}
\hline \hline & & & & Performance \\
& Inflation & Risk & Money Supply & Mutual Funds \\
\hline \hline Mean & 4,5742 & 1,8617 & 4,7398 & 0,8780 \\
Median & 3,8092 & 0,8422 & 4,6985 & 0,3148 \\
Maximum & 6,3825 & 11,4161 & 5,1632 & 9,3479 \\
Minimum & 3,5308 & $-2,3757$ & 4,3577 & $-3,9522$ \\
Std. Dev. & 1,2924 & 3,3106 & 0,3324 & 2,7413 \\
\hline \hline
\end{tabular}

Table 3 Chow Test Result

\begin{tabular}{lrrr}
\hline \hline Effects Test & Statistic & df & Prob. \\
\hline \hline Cross-section F & 1.243412 & $(24,47)$ & 0.2563 \\
Cross-section Chi-square & 36.870165 & 24 & 0.0451 \\
\hline \hline
\end{tabular}


Table 4 Hausman Test Result

\begin{tabular}{lrrr}
\hline \hline Test Summary & $\begin{array}{l}\text { Chi-Sq. } \\
\text { Statistic }\end{array}$ & Chi-Sq. df & Prob. \\
\hline \hline Cross-section random & 0.000000 & 3 & 1.0000 \\
\hline \hline
\end{tabular}

Table 5 Langrage Test Result

\begin{tabular}{|c|c|c|c|}
\hline & \multicolumn{3}{|c|}{ Test Hypothesis } \\
\hline & Cross-section & Time & Both \\
\hline Breusch-Pagan & $\begin{array}{l}0.378924 \\
(0.5382)\end{array}$ & $\begin{array}{l}1.562500 \\
(0.2113)\end{array}$ & $\begin{array}{l}1.941424 \\
(0.1635)\end{array}$ \\
\hline Honda & $\begin{array}{l}0.615568 \\
(0.2691)\end{array}$ & $\begin{array}{c}-1.250000 \\
--\end{array}$ & $\begin{array}{c}-0.448611 \\
--\end{array}$ \\
\hline King-Wu & $\begin{array}{l}0.615568 \\
(0.2691)\end{array}$ & $\begin{array}{c}-1.250000 \\
--\end{array}$ & $\begin{array}{c}-1.030233 \\
--\end{array}$ \\
\hline Standardized Honda & $\begin{array}{l}0.630635 \\
(0.2641)\end{array}$ & $\begin{array}{c}-5.73 E-07 \\
--\end{array}$ & $\begin{array}{c}-4.923780 \\
-\end{array}$ \\
\hline Standardized King-Wu & $\begin{array}{l}0.630635 \\
(0.2641)\end{array}$ & $\begin{array}{c}-5.73 \mathrm{E}-07 \\
--\end{array}$ & $\begin{array}{c}-7.989714 \\
--\end{array}$ \\
\hline Gourieroux, et al.* & - & -- & $\begin{array}{l}0.378924 \\
(>=0.10)\end{array}$ \\
\hline \multicolumn{4}{|l|}{ ^Asymptotic critical values: } \\
\hline $1 \%$ & 7.289 & & \\
\hline $5 \%$ & 4.231 & & \\
\hline $10 \%$ & 2.952 & & \\
\hline
\end{tabular}

\section{Table 6 Regression Data Panel}

Dependent Variable: KINERJA

Method: Panel EGLS (Cross-section weights)

Date: 01/04/19 Time: 02:12

Sample: 20152017

Periods included: 3

Cross-sections included: 25

Total panel (balanced) observations: 75

Linear estimation after one-step weighting matrix

Cross-section weights (PCSE) standard errors \& covariance (df corrected)

\begin{tabular}{lrlrl}
\hline \hline \multicolumn{1}{c}{ Variable } & Coefficient & Std. Error & t-Statistic & Prob. \\
\hline \hline C & 12.46075 & 0.286077 & 43.55732 & 0.0000 \\
INF & -0.300002 & 0.006514 & -46.05584 & 0.0000 \\
TR & 0.969256 & 0.004109 & 235.8880 & 0.0000 \\
& -2.534714 & 0.057131 & -44.36679 & 0.0000 \\
\hline \hline & Weighted Statistics & \\
\hline \hline R-squared & 0.999812 & Mean dependent var & 1.685242 \\
Adjusted R-squared & 0.999804 & S.D. dependent var & 5.527193 \\
S.E. of regression & 0.073573 & Sum squared reside & 0.384321 \\
F-statistic & 125913.7 & Durbin-Watson stat & 1.476603 \\
Prob(F-statistic) & 0.0000000 & & \\
\hline \hline & Unweighted Statistics & \\
\hline \hline
\end{tabular}

